\title{
Evaluative words in Youth's Views, Wants, and Expectations on "Kampung Bahari" Tambak Lorok as a New Semarang Tourism Destination, Indonesia
}

\author{
Deli Nirmala \\ \{deliundip@gmail.com\} \\ Department of Linguistics, Faculty of Humanities, Diponegoro University \\ Jl. Prof. Soedarto, Tembalang, Semarang, 50275, Indonesia
}

\begin{abstract}
Changing world can cause changes in experiences embodied in human mind. The changes can be identified from the expressions used in views, wants, and expectations regarding the development of "Kampung Bahari" which can be a new potential tourism destination in Semarang, which can bring up social economy and even identity of the society. This paper is aimed to discover the youth's views, wants, and expectations regarding to the changing Tambak Lorok represented in the youth's expressions in their writing. Using inferential method, the author can infer the youth's views, wants, and expectations from the evaluative words which are mostly adjectives. The results indicate that the youth's views on Kampung Bahari tend to be positive. Their wants and expectations are that Tambak Lorok with Kampung Bahari will give better environment, economy, and education. This study can support the discussion about the relationship between language, thought, and culture.
\end{abstract}

Keywords: Tambak Lorok; Kampung Bahari; evaluative; views; wants; expectations.

\section{Introduction}

Studying evaluative words has been done by some researchers like [1], [2], [3]. They investigated evaluative words with different perspectives. For example, [3] studied children aged $3-6$ years in using evaluative words regarding emotion in telling their happiness, sadness, anger, for example. Dealing sentimental analysis, [4] studied sentimental appeal related to paternity in two novels Uncle Tom's Cabin and Oby-Dick. However, what the current research focuses on has not been studied yet. It studies evaluative words used by the youth of Tambak Lorok in viewing, hoping, and expecting better life regarding to the development of Kampung Bahari. The current study investigates the evaluative words from cognitive linguistic point of view. The purpose of this research is to find out the use of evaluative expressions of the youth of Tambak Lorok regarding to the physical and social development of Tambak Lorok since it was designed as Kampung Bahari. This is important because of youth involvement in social movement.

Evaluative words are those realized with attitudinal lexis which can be characterized based on the judgment contained in the words. They may refer to positive or negative judgments. Positive judgment refers to situation which indicates enjoyment or comfort in life. However, negative judgment refers to discomfort or inadequacy. According to [5], evaluative words are considered as epithet of which it indicates some 
quality of the entity. Epithet can be classified as an objective property of something, or it may refer to an expression of the speaker's subjective attitude toward it. It may function as experiential epithet and interpersonal epithet.

Language represents experiences, feelings, and thoughts [6] The idea is supported by [7] stating that, in this case, what human has experienced, felt, and thought in their life are embodied and expressed through their words. In evaluation, someone uses his/her experiences, feeling, and thought whether it fulfills a certain standard expected or not. As mentioned earlier, the result of the evaluation can be grouped into positive and negative ones. Positive result refers to something that can be characterized that something has good performances. However, negative result may be some quality that we do not like, that it is bad, that it is inadequate.

\section{Method}

The data were the youth's writing on their views, wants, and expectations regarding to the new Tambak Lorok as Kampung Bahari. Collected using non-participant observation, the data were analyzed using referential [8] and inferential methods [9]. The kinds of evaluative words used in figuring out their changing environment and surrounding of Kampung Bahari can be classified based on their judgement. The referential method was used for finding the meaning of the expressions used, while the inferential method was used for finding out the proposition of the clauses containing evaluative words. It includes presuppositions contained in the expressions that may be triggered by the words leading to presuppositions like proper nouns indicating existential presupposition that shows something exists.

\section{Results and Discussion}

\subsection{Evaluative Words in Views, Wants, and Expectations about Kampung Bahari}

In Bahasa Indonesia, evaluative words are those containing evaluation or judgement that regards to condition, situation, status, or feeling that may refer to enjoyment of life which deals with positive or negative evaluation or judgement. As mentioned before, the judgement can be positive or negative. The positive judgement may refer to good or bad condition, existence or absence of entity, improvement, stability. In this study, the evaluative expressions may be realized as lexical items for positive judgement like bagus (good), sempurna (excellent), memuaskan (satisfactory), nyaman (comfortable), meningkat (increasing), maju (modern / developing), berkembang (developed). In using the expressions, the users give the ranges referring to low or high status, which are expressed with qualifying words like sangat (very), cukup (fair), tidak (no), belum (not yet) depending on the standards / criteria proposed.

\subsubsection{Views}

Views regarding Kampung Bahari are expressed by the young people of Tambak Lorok using words or expressions dealing with several perspectives among other things infrastructure, environment, socio-economy, and dignity of the society of Kampung Bahari. In terms of its infrastructure, their views on the existing condition of Tambak Lorok are expressed through the expressions which can be categorized as positive or near negative evaluation such as infrastruktur belum cukup baik, pembangunan belum stabil, belum terdapat peraturan yang dipahami masyarakat. From the expressions belum cukup, belum stabil, belum terdapat can be 
considered as negative evaluation about a certain condition. These evaluative words or expressions are based on their embodied experiences indicating the missing of or the disappearance of an entity. Since the youth of Tambak Lorok has visual experiences that indicate the adequacy of the infrastructure, their view can be influenced by the experience. According to Evans and Green (2006) language can express what people think, feel, and do. For example, from the expressions infrastruktur belum cukup baik (the infrastructure has not yet been good), the speaker uses the evaluative expression belum cukup baik based on his / her visual experience which can categorize whether something is good, fairly good, or bad. Kampung Bahari has positive or negative evaluation based on their experience in their life in Tambak Lorok.

\subsubsection{Wants}

The expressions used for indicating wants can be characterized from the words ingin, keinnginan, berkeinginan. Sometimes wants are not explicitly stated. In evaluating the condition of Kampung Bahari, the respondents used the word tambah banyak / sering dikunjungi wisatawan asing. The word tambah can also be categorized as a qualifying word since the word can give qualification which indicate changes to be more / better / increase. In Bahasa Indonesia, the word tambah can be combined with adjective indah, cantik, bagus, maju, tinggi, kaya, kuat, tua, for instance. This implies that something changes from lower level to higher one, from being bad to good / beautiful, from being undeveloped to developed, etcetera.

\subsubsection{Expectations}

Similar to wants, expectations also happen in the future to exist due to something good. In connection with the development of Kampung Bahari, the youth of Tambak Lorok expects that Kampung Bahari can be a beautiful and clean place to visit not only for domestic tourists but also for foreign ones. The people will become prosperous. This expectation is also supported by other respondents. Moreover, To be a new tourist destination, Kampung Bahari should be free from garbage. It must be clean. It must also be green. The respondents also expect that people can work together to plant trees in order that the environment of Kampung Bahari can be green and beautiful. Besides, it can be protected from flood.

They expect that children education should be better. It is supported by the changing mindset that youth must become a pioneer as a social agent to change the society of Tambak Lorok. The expressions used for showing expectations in Bahasa Indoneisia among other things harapan saya (my expectation), saya berharap (I expect that), semoga. The word semoga in Bahasa Indonesia cannot be translated lexically. It must be integrated in minor or major clauses like semoga bermanfaat, semoga sukses, semoga lancar. The expression can be expressed in English as I hope that Kampung Bahari will be beneficial for the society in terms of its economy in order that they can live prosperously. The expression semoga bermanfaat can stand alone as a full discourse. It depends on the expression prior to or the context surrounding.

\subsection{Embodied Experiences regarding to Kampung Bahari}

Embodied experiences, according to cognitive linguists, affect the words expressed since they are felt from maybe their visual experiences or physical experiences or behavioral experiences. These objectively can be witnessed by body that can be universally proven. For example, hot temperature can be measured using temperature apparatus. In a certain degree, someone can bare or not. On the other hand, cold temperature can also be felt or experienced.. 
This can be analyzed through the proposition contained in the expressions used by the youth. The expressions dealing with wants, expects, and expectations represent experiences happening in the past which had bad quality.

Using presupposition triggers [10] in analyzing the speaker meaning. For example, that the evaluative word perlu indicates that the roads are embodied that they are in bad condition. The word perlu (need) contains presupposition that the road is suggested to be fixed. The suggestion happens due to the existing condition of the road is not as expected. It is in the condition which does not meet the requirement for being good. Therefore, the respondent expected that the road should be better.

\subsection{Values implied in Kampung Bahari}

From the expressions presented by the youth, it can be seen that the values implied refer to togetherness, cleanliness of the environment, good education, and economic prosperity. The values can be inferred from the expressions containing evaluation in seeing the situation or condition of the housing area which was not proper for living. The society wanted the area to change in terms of infrastructure and social behavior especially in maintaining the area from garbage and slum. Being changed becomes a spirit of the youth of Tambak Lorok. The changes will happen if they collaborate in completing all the problems faced. The expression saling bergotong royong (collaboration) implies a value that collaboration among the social members is very important for reaching the goal that is to make the area greener or cleaner. Social participation is the key in making the are comfortable for living.

To be better becomes the spirit of the youth of Tambak Lorok. The spirit can motivate the youth in involving themselves to be a part of the social changes. They become a pioneer in creating an activity which can support the spirit. Ulil Abshor is the leader of the youth saying that the youth is the agent of change. Therefore, they must change the mindset to change.

\section{Conclusion}

Evaluative words in views, wants, and expectations can reflect the embodied experiences which may need improvement to make them better. This may imply that those become the input for the government in making decision regarding social development. Involvement of the society will create bottom-up policy which may create social involvement in sustaining the programs provided for them. This study can be a model of linguistic research that can give contribution to policy maker. In addition, this research may indicate the truth that happens to the society. This will be supported if the respondents should not have mentioned their names, meaning it must be anonymous.

Acknowledgments. I would like to express my gratitudes to the Dean of the Faculty of Humanities, Diponegoro University, Indonesia for the research funds granted in DIPA FIB 2019, the students of Master Program in Linguistics, Diponegoro University, Najma, Evi, Rizky, Rizka, Sella, and Feby, and Ulil Absor, the youth coordinator of Tambak Lorok.

\section{References}


[1]. M. D. Rocklage, Derek D. Rucker, L. F. Nordgren, Behav Res, 50:1327-1344 DOI 10.3758/s13428017-0975-6, The Evaluative Lexicon 2.0: The measurement of emotionality, extremity, and valence in language (2018)

[2]. K. Karimi and Reza Biria, Sex Roles, Vol. 45, Nos. 11/12, December 2001, Exploring Emotive Verbs in Persian and English Short Stories: A Contrastive Sociopragmatic Approach (2002)

[3]. C. Peterson and M. Biggs, J Psycholinguist Res (2017) 46:415-432 DOI 10.1007/s10936-016- 94431 I, Was Really, Really, Really Mad! Children's Use of Evaluative Devices in Narratives About Emotional Events (2017)

[4]. D. J. Rosenthal, Studies in Literature and Language, Vol. 56, No. 2, Summer 2014, The Sentimental Appeal to Salvific Paternity in Uncle Tom's Cabin and Moby-DickTexas the University of Texas Press DOI: 10.7560/TSLL56202 (2014)

[5]. M.A.K. Halliday, An Introduction to Functional Grammar, third edition, revised by Christian M.I.M. Matthiessen, Arnold, New York, (2004)

[6]. V. Evans and M. Green, Cognitive Linguistics: An Introduction. Edinburgh University Press, Edinburgh (2006)

[7]. G. Lakoff and M. Johnson, Philosophy in the Flesh: the Embodied Mind and its Challenge to Western Thought, Basic Books, A Member of the Perseus Books Group, New York (1999)

[8]. Sudaryanto, Metode dan Aneka Teknik Analisis Bahasa: Pengantar Penelitian Wahana Kebudayaan secara Linguistis, Sanata Dharma University Press, Yogyakarta (2015)

[9]. K. Krippendorff, Content Analysis: An Introduction to Its Methodology, Sage Publications, Inc., California (2004)

[10]. G. Yule, Pragmatics, Oxford University Press, Oxford (1996) 